Gut, 1976, 17, 781-786

\title{
Contrasting features and responses to treatment of severe chronic active liver disease with and without hepatitis $B_{s}$ antigen ${ }^{1}$
}

\author{
S. W. SCHALM, ${ }^{2}$ W. H. J. SUMMERSKILL, ${ }^{3}$ G. L. GITNICK, AND \\ LILA R. ELVEBACK \\ From the Gastroenterology Unit and Section of Medical Research Statistics, Mayo Clinic and Mayo \\ Foundation, Rochester, MN, and the Department of Gastroenterology, University of California, \\ Los Angeles, California, USA
}

SUMMARY To determine the clinical implications of $\mathrm{HB}_{\mathrm{s}} \mathrm{Ag}$ in severe chronic active liver disease (CALD), patients with $\mathrm{HB}_{\mathrm{S}} \mathrm{Ag}$ positive CALD were compared with those chosen by identical clinical, functional, and morphological criteria in whom this test and anti-HB $B_{s}$ were negative. $\mathrm{HB}_{\mathrm{s}} \mathrm{Ag}$ positive patients were predominantly males over 40 years of age and more frequently failed to respond to conventional treatment programmes with prednisone. $\mathrm{HB}_{\mathrm{s}} \mathrm{Ag}$ negative patients were more often female and younger, had a higher incidence of associated immunopathic disease and immunoserological markers in high titre, and more often responded to treatment with full remission of their disease. $\mathrm{HB}_{\mathrm{s}} \mathrm{Ag}$ positive patients failing treatment with conventional doses of prednisone often improved with higher doses, but did not reach full remission of their disease. The benefit-risk ratio of both conventional and high doses of prednisone in $\mathrm{HB}_{\mathbb{8}} \mathrm{Ag}$ positive severe CALD needs further clarification.

The discovery of $\mathrm{HB}_{\mathrm{S}} \mathrm{Ag}$ as a serum marker of hepatitis B virus (Blumberg et al., 1967) allows identification of patients in whom initiation and/or perpetuation of the liver disease is attributable to hepatitis B infection. However, the specific features of CALD associated with $\mathrm{HB}_{\mathbb{S}} \mathrm{Ag}$ in CALD are poorly defined.

Several investigators (Bulkley et al., 1970; Dudley et al., 1972; Finlayson et al., 1972; Reed et al., 1973; Van Waes et al., 1974) have compared findings in groups of $\mathrm{HB}_{\mathrm{s}} \mathrm{Ag}$ positive and negative CALD, which were not selected by pre-established

\footnotetext{
1Presented at the Annual Meeting of the American College of Physicians, San Francisco, 1975. The work was supported in part by Research Grant AM-6908 from the U.S. Public Health Service, Bethesda, MD, and a Grant-in-Aid from Burroughs Wellcome Company.

${ }^{2}$ Eli Lilly Fellow and recipient of a Travel Grant of the Netherlands Organization for Advancement of Pure Research (ZWO). Present address: Department of Gastroenterology, University of Leyden Hospital, Leyden, The Netherlands.

${ }^{8}$ To whom reprint requests should be addressed.
}

Received for publication 15 June 1976 criteria. Differences in sex, age, and incidence of non-organ specific immunoserological markers have been described, but only the predominance of males in $\mathrm{HB}_{\mathrm{S}} \mathrm{Ag}$ positive CALD as opposed to the female predominance in $\mathrm{HB}_{\mathrm{s}} \mathrm{Ag}$ negative cases has been a uniform finding. Chronic hepatitis associated with $\mathrm{HB}_{\mathrm{S}} \mathrm{Ag}$ has been considered to have a milder course and better prognosis than when the antigen is absent (Sherlock, 1974). One retrospective report (Dudley et al., 1973) indicates that prednisone therapy in $\mathrm{HB}_{\mathbf{s}} \mathrm{Ag}$ positive chronic liver disease is followed by clinical and biochemical improvement, but fails to define a definite therapeutic role of corticosteroids, whereas another (Aronoff et al., 1973) suggests that prednisone and/or azathioprine might have an adverse effect.

We have a treatment programme for patients with severe CALD who differ from those in other series by their homogeneity, particularly with regard to the severity of the liver disease, standardisation of therapies, and regularity of follow-up (Soloway et al., 1972). The presence or absence of $\mathrm{HB}_{\mathrm{s}} \mathrm{Ag}$ were not factors in selection or subsequent treatment. A comparison of $\mathrm{HB}_{\mathbf{s}} \mathrm{Ag}$ positive and negative patients in this group has been made to 
investigate differences in responses to therapy with prednisone, as well as to clarify variations in initial clinical and immunoserological features.

\section{Methods}

Postpubertal patients were eligible for our treatment programme if they fulfilled the predetermined criteria of chronicity and activity and had features compatible with CALD on liver biopsy. Chronicity was defined as disease duration of 10 weeks without improvement, or the presence of cirrhosis on liver biopsy. Activity was defined as SGOT elevation $\times 10$ upper limit of normal $(\mathrm{N} 24 \mathrm{IU} / \mathrm{l})$ or SGOT elevation $\times 5$ in combination with a two-fold or more increase in gamma (N 1.6 g/dl) (Geall et al., 1968; Soloway et al., 1972). Histological features included chronic active ('aggressive') hepatitis (de Groote et al., 1968); subacute hepatitis, characterised by bridging or multilobular necrosis; or cirrhosis with active hepatitis (Baggenstoss et al., 1972). Coded biopsies were interpreted by the same observer, who also recorded the presence and degree of features consistent with viral hepatitis (acidophilic cell necrosis, cell ballooning, lobular disarray, and Kupffer cell hyperplasia). Alcoholic liver disease, primary biliary cirrhosis, Wilson's disease, druginduced liver disease, and other conditions were excluded by appropriate methods.

One hundred and thirty-six patients who were randomised to different therapies form the basis of the current report. Treatments (Soloway et al., 1972; Summerskill et al., 1975) comprised maintenance doses of prednisone $(20 \mathrm{mg}$ daily), prednisone (10 mg daily) together with azathioprine (50 $\mathrm{mg}$ daily) or prednisone given on alternate days in doses sufficient to suppress abnormal liver function tests (mean $20 \mathrm{mg}$ on alternate days; range 10-50 $\mathrm{mg}$ ). In all instances, higher doses of prednisone were given initially. In addition, some patients had been randomised to azathioprine (100 $\mathrm{mg}$ daily) or placebo until 1971, when these were discontinued because of inferior results (Soloway et al., 1972).

Patients were seen at six month intervals, when standardised clinical, biochemical, immunoserological, and histological evaluation was performed. Results of treatment comprised clinical and biochemical resolution; full (histological) remission; treatment failure and death (Soloway et al., 1972). Clinical and biochemical resolution comprised absence of symptoms, return of the patient to customary activities, and normal results of standard liver function tests, apart from a two-fold elevation of SGOT. Full remission, in addition to these features, required disappearance from the liver biopsy of histological features of disease activity, the appearances being normal or those of non-specific (identical with chronic persistent) hepatitis. Treatment failure was defined as the onset of hepatic coma, the development of ascites, increasing jaundice (serum bilirubin $66 \%$ above the lowest previous level and above $4 \mathrm{mg} \%$ ) or a $66 \%$ increase in SGOT above the lowest previous value during treatment.

$\mathrm{HB}_{\mathrm{s}} \mathrm{Ag}$ was sought in initial and serial six month serum samples (stored at $-10^{\circ} \mathrm{C}$ ) by radioimmunoassay (Ausria II Abbott) (Ling and Overby, 1972); the passive hemagglutination test (Vyas and Shulman, 1970) and, later, a radioimmunoassay (Ausab, Abbott) (Peterson et al., 1973) were used for detection of anti-HBs. These measurements, as well as other biochemical and immunoserological determinations, were made in laboratories unaware of the diagnosis.

Eighteen patients had $\mathbf{H B}_{\mathrm{s}} \mathrm{Ag}$ detected in their serum on at least one occasion and six patients had anti-HB $\mathrm{B}_{\mathrm{s}} ; 112$ patients were repeatedly negative for $\mathrm{HB}_{\mathrm{s}} \mathrm{Ag}$ and anti-HB . All patients except one were North American Caucasians without a history of drug addiction. $\mathrm{HB}_{\mathrm{s}} \mathrm{Ag}$ positive patients were compared with $\mathrm{HB}_{\mathrm{s}} \mathrm{Ag}$ and anti-HB $\mathrm{B}_{\mathrm{s}}$ negative patients for clinical, biochemical, immunoserological, and histological variables, and response to treatment. Statistical analyses were done by chi-square analysis or Fisher's exact test, for dichotomous variables, and by Wilcoxon rank sum tests for continuous variables. Because of possible interrelationships between the variables under study, linear discrimination methods were subsequently used to select that subset of variables which best contributed to discrimination between the $\mathrm{HB}_{\mathrm{s}} \mathrm{Ag}$ positive and negative patients. The variables employed were age, sex, SGOT, bilirubin, prothrombin time, serum albumin, serum gamma globulin, presence of associated immunopathic disease, and immunoserology.

Survival curves were calculated by the product limit method (Kaplan and Meier, 1958). Since major differences in sex, age, and immunoserology were found between the groups, the responses to treatment in the $\mathrm{HB}_{\mathrm{s}} \mathrm{Ag}$ positive group were also compared with that of $\mathrm{HB}_{\mathrm{s}} \mathrm{Ag}$ negative groups of similar size, matched for histology, treatment group, sex, age, and immunoserology. Matching was done by an independent observer and by computer. Statistical evaluation was done by the use of Cochran's test for matched pairs (Cochran, 1950).

\section{Results}

ENTRY FEATURES: All PATIENTS (Table 1) $\mathrm{HB}_{8} \mathrm{Ag}$ positive patients showed a predominance of 
Table 1 Initial features in chronic active liver disease (all patients)

\begin{tabular}{|c|c|c|}
\hline & $\begin{array}{l}\mathrm{HB}_{s} \boldsymbol{A g} \\
\operatorname{pos}(18)\end{array}$ & $\begin{array}{l}\mathrm{HB} B_{s} \mathrm{Ag} \\
\text { neg (112) }\end{array}$ \\
\hline \multicolumn{3}{|l|}{ Clinical features } \\
\hline Sex, male & $13(89)$ & $34(30) *$ \\
\hline Age, yr (median) & 52 & $35^{*}$ \\
\hline Duration of symptoms $>12 \mathrm{mo}$ & $10(56)$ & 37 (33) \\
\hline Ascites & $2(11)$ & 15 (13) \\
\hline Associated immunopathic diseases & $1(6)$ & $31(28)^{*}$ \\
\hline \multicolumn{3}{|l|}{ Biochemical features } \\
\hline Bilirubin, mg/dl (median) $\mathrm{N}:<1 \cdot 1$ & 1.9 & $3 \cdot 8^{*}$ \\
\hline SGOT IU $/ 1$ (median) $\mathrm{N} \leq 24$ & 502 & 515 \\
\hline Prothrombin time, $\mathrm{s}$ (median) $\mathrm{N} \leq 19$ & 20 & 21 \\
\hline Albumin, $\mathrm{g} / \mathrm{dl}$ (median) $\mathrm{N} \leq 3.3$ & 3.4 & $2 \cdot 8^{*}$ \\
\hline Gamma globulin, g/dl (median) $\mathrm{N} \leq 1.6$ & $2 \cdot 2$ & 3.3* \\
\hline \multicolumn{3}{|l|}{ Immunoserological features } \\
\hline LE, ANA, SMA, and AMA, neg & $10(56)$ & $7(6)^{*}$ \\
\hline LE, ANA, or SMA $\geq 1: 40$ pos & $1(6)$ & $85(76)^{*}$ \\
\hline \multicolumn{3}{|l|}{ Histological features } \\
\hline Chronic active hepatitis & $4(22)$ & $29(26)$ \\
\hline Subacute hepatitis & $9(50)$ & $59(53)$ \\
\hline Cirrhosis with active hepatitis & $5(28)$ & $23(21)$ \\
\hline 'Viral features' (in addition) & 7 (39) & 45 (40) \\
\hline
\end{tabular}

${ }^{*} \mathrm{P}<0.05$. Percentages in parentheses.

males, in contrast with the female preponderance in $\mathrm{HB}_{\mathrm{s}} \mathrm{Ag}$ negative patients, and the age of $\mathrm{HB}_{\mathrm{s}} \mathrm{Ag}$ positive patients was greater. $\mathrm{HB}_{\mathrm{s}} \mathrm{Ag}$ negative patients had a higher incidence of associated immunopathic disease, comprising eight examples of ulcerative colitis, seven patients with thyroiditis, and the remainder with Sjogren's syndrome, scleroderma, cutaneous lupus erythematosus, rheumatoid arthritis, iritis, myasthenia gravis, idiopathic thrombocytopenic purpura, or pernicious anaemia. By contrast, diseases attributable to $\mathrm{HB}$ antigenantibody complex deposition (Gocke et al., 1970; Combes et al., 1971) were limited to two $\mathrm{HB}_{\mathrm{s}} \mathrm{Ag}$ positive patients with periarteritis nodosa and immune-complex glomerulonephritis respectively.

Abnormalities in serum bilirubin, albumin, and gamma globulin were less in patients with $\mathrm{HB}_{\mathrm{g}} \mathrm{Ag}$, but results of other liver function tests were similar. Differences were found in the incidence of so-called immunoserological markers. Lupus erythematosus (LE) cell, antinuclear antibody (ANA), smooth muscle antibody (SMA), and antimitochondrial antibody (AMA) were all negative in approximately $50 \%$ of $\mathrm{HB}_{\mathrm{B}} \mathrm{Ag}$ positive patients, whereas one or more tests were positive in high titre $(\geq 1: 40)$ in $75 \%$ of the $\mathrm{HB}_{\mathrm{s}} \mathrm{Ag}$ negative patients.

The extent and characteristics of the histological lesions in $\mathrm{HB}_{\mathrm{S}} \mathrm{Ag}$ positive CALD resembled those in the negative group. In particular, histological features consistent with viral hepatitis were equally frequent in both.

By linear discrimination methods, the subset of variables making a significant contribution were those representing immunoserology, age, and sex, in that order. The resulting discriminant function gave median values of 6.0 for the $\mathrm{HB}_{\mathrm{S}} \mathrm{Ag}$ negative and 0.8 for the $\mathrm{HB}_{\mathrm{S}} \mathrm{Ag}$ positive. The region of overlap between the groups (scores less than 4) contained all $18 \mathrm{HB}_{\mathrm{S}} \mathrm{Ag}$ positive patients and only $17 \%$ of the 112 negative patients. The total ranges of the scores was -1.4 to +3.85 for positive patients and -0.4 to $+8 \cdot 1$ for those who were negative. Thus, differences in sex, age, and immunoserology each remained significant.

\section{RESPONSES TO TREATMENT WITH PREDNISONE} (Table 2)

Of the $18 \mathrm{HB}_{\mathrm{s}} \mathrm{Ag}$ positive patients, 13 treated with prednisone, with or without azathioprine, have reached an end-point (histological remission or treatment failure) or have been treated for longer than 12 months (average 24 months). $\mathrm{HB}_{\mathrm{s}} \mathrm{Ag}$ positive patients reached clinical and biochemical resolution and histological remission significantly less frequently when compared with all 82 patients without $\mathrm{HB}_{8} \mathrm{Ag}$ who received prednisone treatment. Also, treatment failure and death were significantly more frequent in $\mathrm{HB}_{\mathrm{S}} \mathrm{Ag}$ positive patients.

When these $13 \mathrm{HB}_{\mathrm{s}} \mathrm{Ag}$ positive patients were compared with the same number of matched $\mathrm{HB}_{\mathrm{s}} \mathrm{Ag}$ negative patients, $\mathrm{HB}_{\mathrm{s}} \mathrm{Ag}$ positive patients again reach histological remission less frequently and more often become treatment failures.

Initial responses of patients to higher $(60 \mathrm{mg}$ daily) doses of prednisone or of the combination (prednisone $30 \mathrm{mg}$ and azathioprine $50 \mathrm{mg}$ daily) were usually as favourable as in $\mathrm{HB}_{\mathbf{s}} \mathrm{Ag}$ negative patients, although two $\mathrm{HB}_{\mathrm{S}} \mathrm{Ag}$ positive patients died during the first month of treatment. However, when doses were reduced to our conventional maintenance levels by a standardised procedure (Soloway et al., 1972), biochemical deterioration followed in six of $11\left(54 \%\right.$ surviving $\mathrm{HB}_{\mathrm{s}} \mathrm{Ag}$ positive patients) but occurred in only one of $13(8 \%)$ of $\mathrm{HB}_{\mathbf{S}} \mathrm{Ag}$ negative patients (Fig. 1). Reinstitution of

Table 2 Response to prednisone therapy in $\mathrm{HB}_{s} \mathrm{Ag}$ positive and $H B_{8}$ Ag negative $C A L D \dagger$

\begin{tabular}{llll}
\hline & $\begin{array}{l}\mathrm{HB}_{8} \mathrm{Ag} \\
n e g(82)\end{array}$ & $\begin{array}{l}\mathrm{HB}_{8} \mathrm{Ag} \\
\operatorname{pos}(13)\end{array}$ & $\begin{array}{l}\mathrm{HB}_{s} \mathrm{Ag} \\
n e g \dagger(13)\end{array}$ \\
\hline $\begin{array}{l}\text { Clinical and biochemical } \\
\quad \text { resolution }\end{array}$ & $66(80)^{*}$ & $6(46)$ & $11(85)$ \\
$\begin{array}{l}\text { Histological remission } \\
\text { Treatment failure }\end{array}$ & $56(68)^{*}$ & $2(15)$ & $10(77)^{*}$ \\
Death, total & $13(16)^{*}$ & $6(46)$ & 1 \\
\hline
\end{tabular}

$* \mathbf{P}<0.05$.

† Matched for morphology and treatment (type and duration), sex, age, and immunoserology.

Percentages in parentheses. 


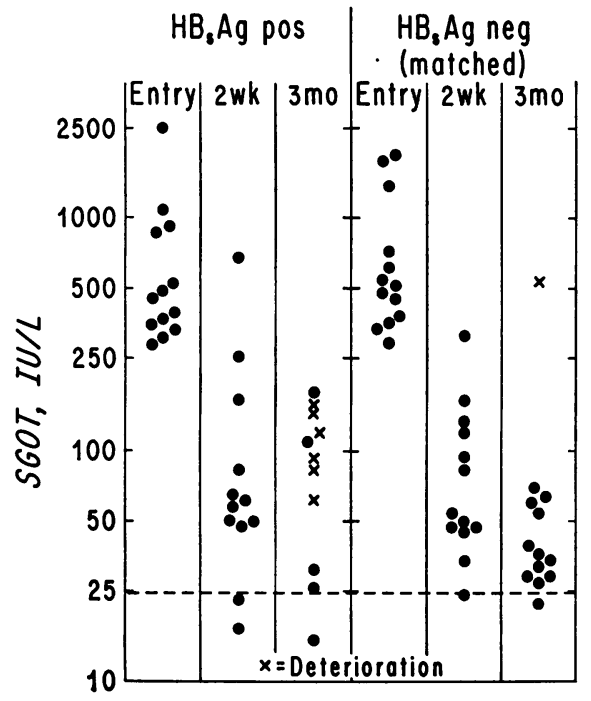

Fig. 1 Effect of prednisone (with or without azathioprine) on SGOT concentration in $\mathrm{HB}$ s Ag positive and $H B_{8} A g$ negative $C A L D$ treated with prednisone.

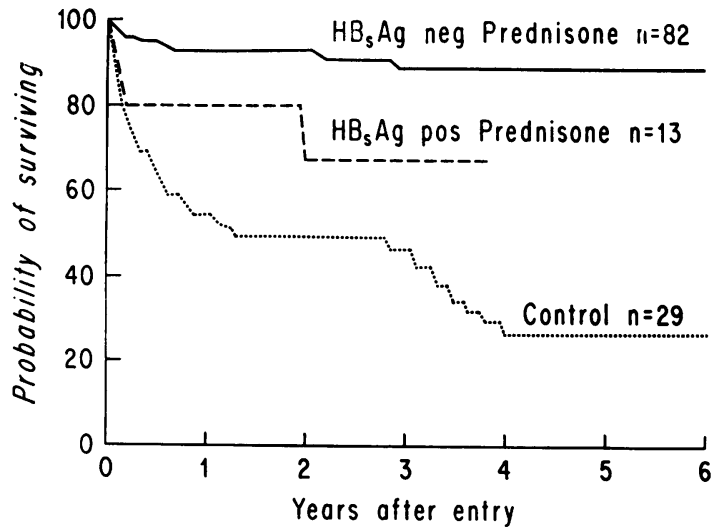

Fig. 2 Cumulative survival of $H B_{s} A g$ positive and $H B_{s} A g$ negative patients with severe CALD treated with prednisone, compared with control treatment group.

higher doses of prednisone resulted in biochemical improvement in all.

Survival curves (Fig. 2) indicate that $\mathrm{HB}_{8} \mathrm{Ag}$ positive patients treated with prednisone have a better prospect of survival than control patients, comprising three $\mathrm{HB}_{\mathrm{s}} \mathrm{Ag}$ positive and 26 negative patients who earlier received azathioprine or placebo. Direct comparison of $\mathrm{HB}_{\mathrm{s}} \mathrm{Ag}$ positive patients with or without prednisone was not feasible because of the small number of $\mathrm{HB}_{\mathrm{S}} \mathrm{Ag}$ positive patients on control therapy; however, the three $\mathrm{HB}_{\mathrm{S}} \mathrm{Ag}$ positive patients did not appear to have a more benign course (two deaths within three years) than $\mathrm{HB}_{\mathbf{s}} \mathrm{Ag}$ negative patients.

\section{TREATMENT RESPONSE RELATED TO}

ANTIGENAEMIA

Ten $\mathrm{HB}_{\mathrm{s}} \mathrm{Ag}$ positive patients have been followed up for more than one year and the antigen has persisted in eight, seven of whom have required continuing treatment. In two patients antigenaemia was transient. Both were under $\mathbf{4 0}$ years of age (whereas all but one of those with persistent antigenaemia were older), and one reached full remission and discontinued treatment two years ago.

\section{Discussion}

The frequency of $\mathrm{HB}_{\mathrm{s}} \mathrm{Ag}$ in our patients with severe CALD was $14 \%$. As prospective studies indicate that $50 \%$ of patients with $\mathrm{HB}_{\mathrm{S}} \mathrm{Ag}$ positive acute viral hepatitis who later develop chronic hepatitis eliminate all detectable amounts of antigen from their serum (Giles et al., 1969; Nielson et al., 1971; Redeker, 1972), our $\mathrm{HB}_{\mathbf{s}} \mathrm{Ag}$ and anti-HB negative patients may include some whose disease was initiated by hepatitis $B$ infection. If so, our $\mathbf{H B}_{\mathbf{s}} \mathrm{Ag}$ positive patients represent a subgroup characterised by failure to eliminate $\mathrm{HB}_{\mathrm{s}} \mathrm{Ag}$ early in their course.

In controlled circumstances, we found that $\mathrm{HB}_{\mathrm{s}} \mathrm{Ag}$ positive patients differ in several clinical and biochemical characteristics from $\mathrm{HB}_{\mathrm{s}} \mathrm{Ag}$, anti- $\mathrm{HB}_{\mathrm{s}}$ negative patients. The predominance of males with $\mathrm{HB}_{\mathrm{S}} \mathrm{Ag}$ positive disease found in previous studies (Bulkley et al., 1970; Dudley et al., 1972; Reed et al., 1973) was confirmed. The higher age of patients with $\mathrm{HB}_{\mathrm{s}} \mathrm{Ag}$ positive disease has also been described in a patient population not addicted to drugs (Dudley et al., 1972) and our finding that patients eliminating the $\mathrm{HB}_{\mathbf{s}}$ antigen were younger may suggest that older individuals do this less effectively.

The association between CALD and immunopathic' diseases mainly involves $\mathrm{HB}_{\mathrm{s}} \mathrm{Ag}$ negative patients, whereas extrahepatic lesions attributable to HB antigen-antibody complexes typify those who are $\mathbf{H B}_{\mathbf{s}} \mathrm{Ag}$ positive. Similarly, the presence of non-organ specific immunoserological markers in high titres is greater in $\mathrm{HB}_{\mathrm{s}} \mathrm{Ag}$ negative patients, whereas their absence is commoner in those who were $\mathrm{HB}_{\mathrm{s}} \mathrm{Ag}$ positive. These findings support differences suggested by others (Bulkley et al., 1970; Finlayson et al., 1972; Dudley et al., 1973) but not universally confirmed (Reed et al., 1973; Van Waes et al., 1974). As the incidence of such 'autoantibodies' failed fully to differentiate between $\mathrm{HB}_{\mathrm{s}} \mathrm{Ag}$ positive and negative patients, and as weakly positive results were not infrequent in both groups, it appears likely that positivity of these 
tests represents alterations in host response, rather than specific aetiologies. Hence, the similar incidence of histological features associated with viral hepatitis in both groups is of interest.

Chronic hepatitis associated with $\mathrm{HB}_{\mathbf{s}} \mathrm{Ag}$ has been considered to have a better prognosis than when the antigen is absent (Sherlock, 1974). However, this generalisation cannot be substantiated when, as in our series, patients selected by uniform clinical, biochemical, and morphological criteria of disease severity are evaluated. In these conditions, we found that $\mathrm{HB}_{\mathrm{s}} \mathrm{Ag}$ positive patients with severe CALD enter remission significantly less frequently and fail therapy significantly more often than do negative patients when treated with prednisone, with or without azathioprine. This finding raises the question of the efficacy of treatment with steroids in $\mathrm{HB}_{\mathrm{S}} \mathrm{Ag}$ positive patients. While the benefit of steroids in CALD has been established in controlled trials Cook et al., 1971; (Soloway et al., 1972; Murray-Lyon et al., 1973), none of these has been restricted to $\mathrm{HB}_{\mathrm{S}} \mathrm{Ag}$ positive patients. Since the number of $\mathrm{HB}_{\mathrm{s}} \mathrm{Ag}$ positive patients in our control group was small, a valid comparison between prednisone treated and untreated patients with $\mathrm{HB}_{\mathrm{s}} \mathrm{Ag}$ was not possible. Our data, however, suggest that therapy is indicated and that higher doses of medication given over longer periods of time may be required for some patients with $\mathrm{HB}_{\mathrm{B}} \mathrm{Ag}$, but the benefits and risks of such therapy await evaluation in a controlled trial.

We appreciate the continuing collaboration of our patients and their home physicians; gratefully acknowledge the assistance of Mrs Audrey Wolf, R.N., in the care of our patients; and are indebted to Dr A. H. Baggenstoss, who evaluated the liver biopsies, and to Dr P. J. Thomas for his continued advice in data analysis.

\section{References}

Aronoff, A., Gault, M. H., Huang, S. N., Lal, S., Wu, K. T., Moinuddin, M. D., Spence, L., and MacLean, L. D. (1973). Hepatitis with Australia antigenemia following renal transplantation. Canadian Medical Association Journal, 108, 43-50.

Baggenstoss, A. H., Soloway, R. D., Summerskill, W. H. J., Elveback, L. R., and Schoenfield, L. J. (1972). Chronic active liver disease. The range of histologic lesions, their response to treatment, and evolution. Human Pathology, 3, $183-198$.

Blumberg, B. S., Gerstley, B. J. S., Hungerford, D. A., London, W. T., and Sutnick, A. L. (1967). A serum antigen (Australia antigen) in Down's syndrome, leukemia, and hepatitis. Annals of Internal Medicine, 66, 924931.

Bulkley, B. H., Heizer, W. D., Goldfinger, S. E., and Isselbacher, K. J. (1970). Distinctions in chronic active hepatitis based on circulating hepatitis-associated antigen. Lancet, 2, 1323-1326.
Cochran, W. G. (1950). The comparison of percentages in matched samples. Biometrika, 37, 256-266.

Combes, B., Stastny, P., Shorey, J., Eigenbrodt, E. H., Barrera, A., Hull, A. R., and Carter, N. W. (1971). Glomerulonephritis with deposition of Australia antigenantibody complexes in glomerular basement membrane. Lancet, 2, 234-237.

Cook, G. C., Mulligan, R., and Sherlock, S. (1971). Controlled prospective trial of corticosteroid therapy in active chronic hepatitis. Quarterly Journal of Medicine, 40, 159-185.

de Groote, J., Desmet, V. J., Gedigk, P., Korb, G., Popper, H., Poulsen, H., Scheuer, P. J., Schmid, M., Thaler, H., Uehlinger, E., and Wepler, W. (1968). A classification of chronic hepatitis. Lancet, 2, 626-628.

Dudley, F. J., O'Shea, M. J., Ajdukiewicz, A., and Sherlock, S. (1973). Serum autoantibodies and immunoglobulins in hepatitis-associated antigen (HAA)-positive and -negative liver disease. Gut, 14, 360-364.

Dudley, F. J., Scheuer, P. J., and Sherlock, S. (1972). Natural history of hepatitis-associated antigen-positive chronic liver disease. Lancet, 2, 1388-1393.

Finlayson, N. D. C., Krohn, K., Anderson, K. E., Jokelainen, P T., and Prince, A. M. (1972). Interrelations of hepatitis B antigen and autoantibodies in chronic idiopathic liver disease. Gastroenterology, 63, 646-652.

Geall, M. G., Schoenfield, L. J., and Summerskill, W. H. J. (1968). Classification and treatment of chronic active liver disease. Gastroenterology, 55, 724-729.

Giles, J. P., McCollum, R. W., Berndtson, L. W., Jr, and Krugman, S. (1969). Relation of Australia/SH antigen to the Willowbrook MS-2 strain. New England Journal of Medicine, 281, 119-121.

Gocke, D. J., Morgan, C., Lockshin, M., Hsu, K., Bombardieri, S., and Christian, C. L. (1970). Association between polyarteritis and Australia antigen. Lancet, 2, 1149-1153.

Kaplan, E. L., and Meier, P. (1958). Non-parametric estimation from incomplete observations. Journal of the American Statistical Association, 53, 457-481.

Ling, C. M., and Overby, L. R. (1972). Prevalence of hepatitis $\mathbf{B}$ virus antigen as revealed by direct radioimmune assay with ${ }^{125}$ I-antibody. Journal of Immunology, 109, 834-841.

Murray-Lyon, I. M., Stern, R. B., and Williams, R. (1973). Controlled trial of prednisone and azathioprine in active chronic hepatitis. Lancet, 1, 735-737.

Nielsen, J. O., Dietrichson, O., Elling, P., and Christoffersen, $P$. (1971). Incidence and meaning of persistence of Australia antigen in patients with acute viral hepatitis: development of chronic hepatitis. New England Journal of Medicine, 285, 1157-1160.

Peterson, M. R., Barker, L. J., and Schade, D. S. (1973). Detection of antibody to hepatitis-associated antigen in hemophilia patients and in voluntary blood donors. Vox Sanguinis, 24, 66-75.

Redeker, A. G. (1972). Chronic viral hepatitis. In Hepatitis and Blood Transfusion, pp. 55-60. Edited by G. N. Vyas, H. A. Perkins, and R. Schmid. Grune and Stratton: New York.

Reed, W. D., Eddleston, A. L. W. F., Stern, R. B., Williams, R., Zuckerman, A. J., Bowes, A., and Earl, P. M. (1973). Detection of hepatitis-B antigen by radioimmunoassay in chronic liver disease and hepatocellular carcinoma in Great Britain. Lancet, 2, 690-694.

Sherlock, S. (1974). Chronic hepatitis. Gut, 15, 581-597.

Soloway, R. D., Summerskill, W. H. J., Baggenstoss, A. H., Geall, M. G., Gitnick, G. L., Elveback, L. R., and Schoenfield, L. J. (1972). Clinical, biochemical, and histological remission of severe chronic active liver disease: a con- 
trolled study of treatments and early prognosis. Gastroenterology, 63, 820-833.

Summerskill, W. H. J., Korman, M. G., Ammon, H. V., and Baggenstoss, A. H. (1975). Prednisone for chronic active liver disease: dose titration, standard dose, and combination with azathioprine compared. Gut, 16, 876883.
Van Waes, L., Segers, J., Van Egmond, J., Van Nimmen, L., Barbier, F., Wieme, R., and Demeulenaere, L. (1974). Chronic liver disease and hepatitis-B antigen: a prospective study. British Medical Journal, 3, 444-446.

Vyas, G. N., and Shulman, N. R. (1970). Hemagglutination assay for antigen and antibody associated with viral hepatitis. Science, 170, 332-333. 